\title{
THE CALL OF NATHANAEL. JOHN 1:49. A RHETORICAL-THEOLOGICAL STUDY
}

\author{
JOHN K. STAFFORD*
}

University of Manitoba

\begin{abstract}
Historicist approaches to the reading of sacred texts, rapidly attain a point where further research produces diminishing returns, resulting in more historical speculation rather than less. This is the opposite of the desired result. The cause of this impasse lies in a failure to discern the rhetorical techniques of the author as a basic reading strategy. Similarly, it is necessary to discern that the author has already made key determinations as to historicity. What is now required of the reader is a deepened appreciation of the intentional theological, ontological and existential implications of the narrative. This paper examines how a literary/rhetorical approach may yield positive results in the case of the call of Nathanael, a narrative fragment that poses intriguing critical questions, both theological and Christological. The results suggest a dominical encounter that supplies the reader with pre-emptive eschatological intensity through deliberate juxtaposition of Nathanael's disbelief and Jesus' selfawareness held together in a matrix of scriptural fulfilment.
\end{abstract}

KEY WORDS: Nathanael, John's Gospel, Literary/rhetorical analysis, Historicism, Sarcasm

\section{Introduction}

The account of Jesus' meeting with Philip and Nathanael early in John's Gospel is the first extended affirmation of John the Baptist's declaration that Jesus is to be understood as the "Lamb of God" (1:29) and "Son of God" (1:34). Andrew's disclosure to Peter that "We have found the Messiah" (1:41) positions the reader for a similar reaction from Philip and Nathanael. However, Nathanael's initial reaction to Jesus is one of great scepticism and disbelief. "Can anything good come from Nazareth?” Yet immediately following Jesus' visionary reply, "I saw you under the fog tree before Philip called you" (1:48), Nathanael responds with what at first sight is a startling declaration of faith and recognition as to the identity of Jesusit is an epiphany experience which seems to be out of proportion to the actual progress of the discourse between Philip, Nathanael and Jesus. How does Na-

* JOHN K. STAFFORD (PhD, University of Manitoba) is associate professor in Biblical Studies at Providence University College, within the University of Manitoba. His teaching fields are Introduction to the Pentateuch, Homiletics, History of Liturgy, and Interpreting Old Testament Narrative. 
thanael's insight follow logically from Jesus' vision of him beneath a fig tree? Why, in a parallel example, does the Samaritan woman consider Jesus only to be a prophet when he reveals similar special knowledge of her domestic circumstances? ${ }^{1}$ Further, need it be the case that Jesus' assumption of Nathanael's belief (1:50) implies actual belief on the part of Nathanael? What Nathanael uttered might not be what Nathanael meant. How are we to account for this highly compressed dialogue? One possibility is that the author of John has constructed a dialogue for the tendentious purpose of arguing that Jesus' true identity was known prophetically at a very early stage of his ministry and that such knowledge was only available by special revelation. A simpler and older variant of this view, maintaining a commitment to historical realism, holds that Nathanael spoke prophetically and historically, the truth of which was confirmed by Jesus' concluding reply $(1: 50){ }^{2}$ In such a historicist view, there is an interpersonal encounter between Jesus and Nathanael and recollection of the discourse spread and became widely known and embedded in the Johannine tradition at least. As such, it became paradigmatic for many similar encounters with Jesus.

However, unless Nathanael is to be equated with Bartholomew, his declaration of Jesus' status did not result in his inclusion among the Twelve. ${ }^{3}$ A historicist reading of the text leads to this expectation. Notwithstanding, the person of $\mathrm{Na}$ thanael is ultimately left as undefined as Nicodemus-in John, the various actors often serve as narrative foils or cyphers, appearing and disappearing as the plot unfolds. A strictly historical approach to the text is therefore unsatisfying because it ignores other aspects of the text that can only be appreciated using literary and narrative critical methods. Applying only the assumptions of historical method results in weakened conclusions because the biblical author has already situated his Gospel firmly within the matrix of culture and history-what historical method cannot do is make John's assessment of Jesus sufficiently plausible to stimulate belief that Jesus is the Christ which is the stated goal of John's Gospel (20:30f) in and

1 John 4:16-19. Jesus knows she is not married to the man she claims to be her husband though there is no obvious way for him to perceive this. Thus, she declares Jesus to be a prophet.

2 For example, J. H. Bernard, A Critical and Exegetical Commentary on the Gospel According to St. John, The International Critical Commentary (Edinburgh: T. \& T. Clark, 1928); B. F. Westcott, The Gospel According to St. John (Grand Rapids: William B. Eerdmans, 1881, reprinted 1981); Leon Morris, Studies in the Fourth Gospel (Grand Rapids: William B. Eerdmans, 1969); Stephen S. Smalley, John. Evangelist and Interpreter (Nashville: Thomas Nelson Publishers, 1984); A. M. Hunter, According to John (Norwich: SCM Press Ltd, 1977); John Painter, John. Witness and Theologian (London: SPCK, 1979).

3 The identity of Nathanael is intriguing. He is introduced to Jesus by Philip who was from Bethsaida though his own home town is not revealed. However, in John 21:2 it is recorded that he was from Cana. While he is identified as associated with the Twelve, this does not require that he was a member of them. Regardless, while his identity is not secure, from a rhetorical perspective, it is much more important to understand how he functions in the narrative for the larger purpose of John's developing Christology.

PERICHORESIS 11.2 (2013) 
of itself. Naturally, this will depend on one's conclusions as to the identity of John's readers. In fact, the Gospels conflate history and theology and do so with rhetorical artistry. This is particularly true in John's Gospel where event and interpretation are intricately woven by the narrator. Although each dimension of the narrator's theological art must be held in solution, it is important to recognize the limitations of historical method if only by virtue of the impossibility of recreating (as though by experiment) any particular event depicted in the text.

The purpose of this article is to test the idea that the present text gives evidence of a rhetorical design that illustrates the theological method employed in John's Gospel to provide a basis for believing that Jesus is the Christ rather than another figure and why this should matter. The article approaches the topic without evaluating historical questions, though it is assumed that encounters with the first disciples took place, including Nathanael, in ways plausibly depicted by the text. Thus no historical skepticism is required in order to explore the literary and narrational horizons of John 1 (or any other text for that matter). The approach taken in this article is that of narrative and rhetorical criticism because the text itself calls forth a reading strategy that does not depend on historical reconstruction in order to yield incisive theological insight. ${ }^{4}$ Such a strategy is suggested by the rhetorical context of John 1 itself and wider examples of sarcasm and understatement in John's Gospel. The article suggests that John 1:43-51 is not an instance of Nathanael's prophetic insight, but rather an example of sarcasm often employed in John's Gospel.

\section{The Context of John 1}

The concern of all the Gospel writers is to authenticate the identity of Jesus as the Christ through his teaching, deeds of power, miracles, crucifixion and resurrection from the dead. This ontological agenda is established at the start of the Gospel narratives and in John's Gospel, the framework of the "signs" represents its rhetorical superstructure. Within the larger structure, numerous microstructures or events are relayed that present a context for the validity of such "signs". The signs themselves appear to function as dogmatic way points that make it possible to identify Jesus as the Christ and not John the Baptist or another person. Such a procedure would only have been necessary if the risk of misidentification was real

For example, James L. Resseguie, Narrative Criticism of the New Testament (Grand Rapids: Baker Academic, 2005); Vernon K. Robbins, Exploring the Texture of Texts. A Guide to Socio-Rhetorical Interpretation (Valley Forge: Trinity Press International, 1996); Vernon K. Robbins, The Tapestry of Early Christian Discourse (New York: Routledge, 1996); Paul Duke, Irony in the Fourth Gospel (Atlanta: John Knox Press, 1985); R. Alan Culpepper, Anatomy of the Fourth Gospel. A Study in Literary Design (Philadelphia: Fortress Press, 1983). 
and already being made when the Gospel was written. ${ }^{5}$ Demarcating John the Baptist and Jesus is already a necessity in the Synoptic Gospels and Acts, and the first chapter of John describes the theological basis for such a distinction. Thus misidentification is used to positive narrational effect. ${ }^{6}$

Nonetheless, the writer of John is faced with a paradox. In the Prologue, the Word became flesh and the created order came to be through him-he, as the uncreated Son, was as unknowable as the mystery of God himself. The question naturally arises about how it was that the narrator himself came to this knowledge of the Son. John's core theme, "who is Jesus?" is necessarily answered by the divine attributes of "grace and truth" (1:14) made available through the actions of God by the Spirit. These attributes are preeminent for John because without them, apprehension of the true identity of Jesus is impossible. That is, all other witnesses to Jesus are indirect and liable to be misconstrued, including the ministry of the Baptist.

This question is honestly brokered in John's Gospel in 1:19-28 through a series of programmatic questions put to the Baptist by priests and Levites (1:19). Thus, "Who are you?", "What then? Are you the Elijah?", "Are you the prophet?", "Who are you?", "What do you say about yourself?", "Why are you baptising?" This section of the Prologue positions John as the Baptiser and closes the debate over his identity at verse 28 but with the enigmatic "Among you stands one whom you do not know" (verse 27). The motif of "knowing" is characteristic of John and reappears at a number of key points in chapter 1. Rhetorically, the motif fuels John's discussion of how Jesus can be known and identified as the Christ. Although the Baptist is clearly established as one who baptized and yet was not the Christ, the same question is not foreclosed regarding Jesus' identity because the Baptist has identified Jesus as the "one greater than I".

The transition section of 1:29-34 identifies Jesus as the "Lamb of God" but continues the theme of "knowing" by finally declaring John's reason for baptizing (previously raised in verse 25) - that "he [Jesus] might be revealed to Israel" (verse 31). It is worth noting that the words of the Baptist, "I myself did not know him" are repeated twice each in verses 31 and 32 which seems to infer that recognition of Jesus as the Messiah was feasible only in terms of heavenly manifestation, that is, by virtue of the Holy Spirit. Therefore, John the Baptist himself could not decisively point to Jesus as the Christ until that manifestation was apparent despite the sense of anticipation. In addition, the revelation of Jesus was made not only to

$5 \quad$ See for example, Acts 18:25, where Apollos knows only the baptism of John, and again at Acts 19:1-7, where the Ephesian disciples are further instructed by Paul concerning the relationship between the Holy Spirit and Christian baptism.

$6 \quad$ Misunderstanding of Jesus' origins would be expected given the claims made about him in any of the Gospel accounts. This can be viewed as a mark of narrative authenticity and clearly John has capitalised on this. See also, Ben Witherington, III, John's Wisdom. A Commentary on the Fourth Gospel (Cambridge: The Lutterworth Press, 1995), 71.

PERICHORESIS 11.2 (2013) 
John but in a limited sense to the world. The varied reception of that revelation becomes a significant burden for the author of the Fourth Gospel.

In the larger body of text which ends at 2:12 following the Wedding Feast at Cana, four chronological markers occur which are suggestive of the acts of creation through him who "... was in the beginning with God" (1:2). "The next day..." $(1: 29,35,43)$ and "On the third day..." (2:1) tie the larger theme of "knowing" and "finding" together. ${ }^{7}$ It is in this section that the call of Nathanael is located and takes up the theme of Jesus' (self-) disclosure. Thus, John moves the reader from public "unknowing" to "knowing" through a process of "finding" precipitated by the Baptist's declaration, but democratised by Andrew's blunt, "We have found the Messiah" (1:41) (emphasis mine) and further stressed by Philip's "We have found him about whom Moses... wrote..." (1:45). ${ }^{8}$ Clearly there is an escalating description of Jesus' identity throughout chapter 1. Initially, one assumes the narrative section explaining Nathanael's calling simply falls into this pattern because, thus far, response to Jesus from his first disciples has been unequivocalwhy would a reader not expect this to continue unless, from a rhetorical point of view, plot complication is necessary to carry the narrative to the next level of reader inquiry and involvement.

Consequently, the first chapter of John should be viewed as a thematic unity that begins and ends with substantially the same concerns but structured to advance the question of Jesus' self-understanding in the world of human contact. This way of construing Jesus' nature can be thought to represent John's approach to the question of incarnation addressed in other ways through the infancy narratives of Matthew and Luke. The philosophic consequences of identifying the Logos with Jesus are matched by the difficulty of assigning sufficient categories to the human experience of him. It is that engagement in particular with which John is deeply concerned, the apposition of limited human understanding and transdecisive for theological purposes though it is hard to see how these are narrative accidents and not consistent with John's plot strategy. Clearly, a creation motif is already at work in John's Gospel from the outset but how this is developed is beyond the present scope. Murray Rae considers John's "seven signs" to be a more convincing creation allusion. See, Murray Rae, "The Testimony of Works in the Christology of John's Gospel”, in The Gospel of John and Christian Theology, ed. by Richard Bauckham and Carl Mosser (Grand Rapids: William B. Eerdmans, 2008), $302 \mathrm{ff}$.

Other commentators view verbal repetition and disjunction as indications of redaction activity or early compositional strata. See, for example, J. Louis Martyn, History and Theology in the Fourth Gospel (Louisville: Westminster John Knox Press, 2003), 147ff. Ultimately, a reconstruction of Johannine literary sources involves a reconstruction of the community that produced these early strata, and its historical circumstances. Such reconstructions are fascinating but only more or less convincing. In the final analysis, the (assumed) strata have no independent existence. In the case of John's Gospel, all we have is the final text wherein the author's theological purposes are disclosed through the coherency of his narrative-in the present case, a very sophisticated narrative.

PERICHORESIS 11.2 (2013) 
cendent knowledge, yet claimed by and for Jesus in the Gospel. I contend that this is the dynamic of the first chapter of John within which verses 43-51 serve a unique and interesting function.

\section{The Call of Nathanael}

As mentioned earlier in the paper, Nathanael's response to Jesus, "Rabbi, you are the Son of God! You are the King of Israel!" (1:49) appears to be an exaggerated reply to Jesus' foreknowledge of Nathanael seated under a fig tree. Such a rapid move from doubt based on Nathanael's stereotypical understanding of the inhabitants of Nazareth, "Can anything good come out of Nazareth?" (1:46), to ontological affirmations about Jesus, seems intrinsically unlikely when viewed as a piece of historical reporting. ${ }^{9}$

One way to understand this unusual discourse is to set it against the backdrop of the Johannine narrative to this point and consider also John's style of writing which regularly employs sarcasm and understatement to formulate a point not easily accessed by an assumed reader. That this is so is predetermined by the way John has introduced Jesus thus far-he is "unknowable" in his role as Christ—“... the world did not know him" (1:10). The process was not iterative but rather declarative and thus demanded exploration of a distinct claim to messianism. Such exploration moves Philip to add new information to John's emerging disclosure of Jesus by announcing his identity with Moses $(1: 17)^{10}$ and the prophets, but also his temporal identity with Joseph and Nazareth (1:45). This elicits Nathanael's scoffing reply at verse 46 .

However, an interesting reversal takes place. Thus far, the narrative has introduced Jesus from the observer's point of view, from below as it were. That is, observers see Jesus "coming" towards them. Again, Philip invites Nathanael to "Come and see" (1:46) but this time the vantage point shifts and Jesus sees Nathanael coming toward him (1:47). Jesus' estimation of Nathanael as "an Israelite in whom there is no deceit" (1:47) immediately places the Israelite identity of Nathanael in the foreground of the discourse and calls up the quintessentially deceitful Israelite, namely Jacob. Now this can hardly be accidental and invites the idea that there might actually be such a person as a "true" Israelite, that is, one who embodies the defining qualities of Israel's relationship with God, him "of whom

Nathanael's attitude towards Nazareth and its inhabitants could reflect local rivalry and is not to be discounted, but the context here is religious. This is Nathanael's response to the notion of a prophet emerging from Nazareth since Nazareth is not mentioned in the Hebrew scriptures. Cf. Matthew 2:2-6, John 7:40-42.

10 John links Jesus to Moses by way of contrast with respect to the Law, but other positive points of contact are available which describe the intimacy of God with Moses. Cf. Exodus 33:11.

PERICHORESIS $11.2(2013)$ 
Moses wrote" $(1: 45) .{ }^{11}$ This excursion into Israel's theology is further strengthened by the observation that again, the discourse reverses and it is Jesus who "sees" Nathanael in response to Nathanael's question, "Where did you get to know me?" (1:48). Further, Jesus observes Nathanael "under the fig tree before Philip called you" (1:48). As Craig Blomberg notes, ${ }^{12}$ the motif of the fig tree was associated in biblical thought with seasons of peace, prosperity, and divine blessing. (cf. 1 Kings 4:25; Micah 4:4; Zechariah 3:10; 1 Maccabees 14:12). The reference in Zechariah carries more obvious eschatological notes.

The key reply of Nathanael to Jesus is certainly one of exclamation and belief. But belief in what? The usual explanation is to assume a dramatic reversal of unbelief transformed to belief. ${ }^{13}$ This view is encouraged by the apparent readiness of Jesus to accept the truth of what Nathanael has just said. Yet this is not quite consistent with the more gradual pattern of messianic recognition in John's Gospel so why would it happen in this instance? Is an instinctual recognition of Jesus' identity based upon so little evidence likely, especially when counter-intuitive ("out of Nazareth") unless a Nathanael has received an extraordinary revelatory disclosure which, of course, cannot in principle be ruled out.

Another explanation is that Nathanael is not expressing belief at all but rather indulging in sarcasm. This is actually in line with Nathanael's stated views regarding people who come from Nazareth. ${ }^{14}$ Since Jesus has perceived Nathanael sitting under a fig tree, thus invoking a well-established metaphor for the peaceable eschatological kingdom, Nathanael responds in like fashion by using similarly wellestablished titles of kingship for Jesus. Thus the reader is thrown into a vigorous be ironic since subsequently, the true Israelite in this discourse is Jesus himself. Bernard, $A$ Critical and Exegetical Commentary on the Gospel According to St. John, 64.

12 Craig L. Blomberg, Jesus and the Gospels: An Introduction and Survey (Nashville: Broadman \& Holman, 1997), 219.

13 Thus Westcott: Nathanael lays aside "all prejudice and doubt and the title is given by instinct which before he had withheld”. Westcott, St. John, 27. Similarly, Bernard has Nathanael replying "out of the fullness of his heart". Bernard, A Critical and Exegetical Commentary on the Gospel According to St. John, 64.

14 Thomas Brodie maintains a literary reading but historicist perspectives are deeply ingrained when describing Nazareth as "so human a place" and yet ruling out any earthly political implications of "King of Israel". For Brodie, the account is one of metaphor-being under the fig tree is a place of darkness, a favourite association of John. However, nowhere does the Bible apply the image of a fig tree to (spiritual) darkness, in fact, generally the opposite. Thus, "The story is one of faith, of someone who from his sheltered and rather sulky place came forth to a new presence and to a new awareness of possibilities. In Johannine terms, it is a story of moving from darkness to light". However, the rhetoric of the story is missed-a literary reading cannot simply be an exercise in unearthing metaphors. Thus, Nathanael simply becomes the prototype for belief which, in my view, distorts the locus of John's narrative design. Thomas $\mathrm{L}$. Brodie, The Gospel According to John. A Literary and Theological Commentary (Oxford: Oxford University Press, 1993), $167 f$. 
reparté between Jesus and Nathanael. ${ }^{15}$ That such a verbal "collision" is taking

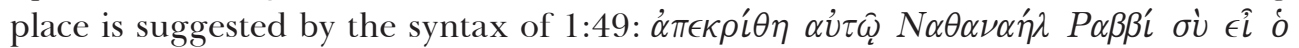

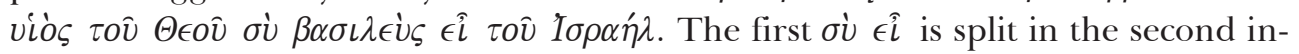
stance by $\beta \alpha \sigma L \lambda \in \dot{\nu} \varsigma$ for no obvious reason. However, a similar construction is found in John 11:21, 32, describing the response of Martha and Mary respectively to Jesus' arrival in their home on the death of their brother Lazarus. ${ }^{16}$ Each verse is identical except for disturbed word order through the split modifier in 11:32 as follows:

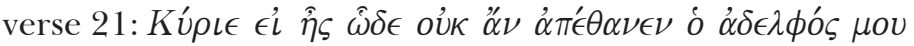

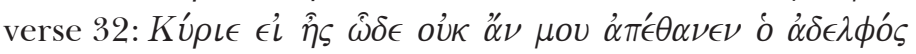

This sort of disturbed word order is grammatically acceptable and can signify emotion or agitation of some kind as the author sees it. ${ }^{17}$ In the case of Mary and Martha, the context supports this since Mary is the sister who is described as weeping, not Martha, and it is in Mary's conditional statement where the split modifier occurs. Although the situation described in 1:49 is quite different, the grammatical representation of emotion or agitation is the same, but here the context supports sarcasm.

Sarcasm is a common feature in John's Gospel and occurs frequently at points where the narrative involves a decisive appraisal of Jesus and his actions. The well-known encounter with Nicodemus presents Jesus expressing mock amazement, "Are you a teacher of Israel, and yet you do not understand these things?" (3:30). In the account of the healing of the man born blind in John 9, John's narrative places biting sarcasm on the lips of the healed man (9:30-33). What happens after such encounters is as important as the encounters themselves by providing a narrative vehicle for the reader's belief (or un-belief). Typically, the initiative in determining the direction of the discourse moves rapidly from the one who encounters Jesus to Jesus himself. The grammatical construction is also of interest because of the unusual word order and the assonance associated with the two in-

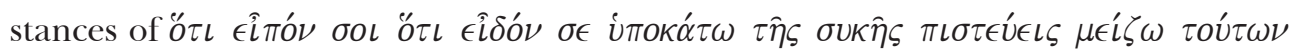

15 Even the title "Rabbi" can be used with irony to imply that Nathanael does not think Jesus has actual rabbinic authority, any more than he might have kingly authority. This further intensifies the interaction.

16 This has been noted by Charles Homer Giblin, "What Was Everything He Told Her She Did? (John 4:17-18, 29, 39)”, New Testament Studies 45 (1999): 150, n. 8, in his subtle narrative and rhetorical reconstruction of John 4:7-42. Giblin considers this to be characteristic of John. go: The University of Chicago Press, 1961), 249, n. 473. Nigel Turner has a restrained view of disturbed word order thinking of it more as oratorical expression. This does, however, move the question in the direction of rhetorical effect. See Nigel Turner, Syntax, Grammar of New Testament Greek (Edinburgh: T. \& T. Clark, 1963), 350. 
$\hat{\delta} \psi \eta$ (1:50). It is at this point that Nathanael disappears from the narrative context

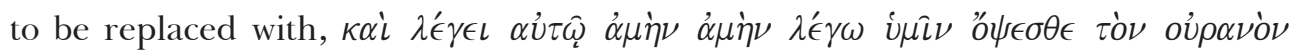

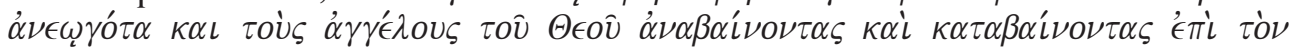

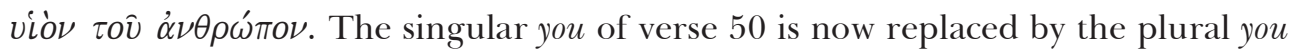
in verse 51 , although Jesus is apparently speaking to Nathanael. In any case, the final narrative image is that of Jesus and the depiction of him as the Ladder of Jacob so to speak. ${ }^{18}$ An identical narrative strategy takes place at 3:11 where the

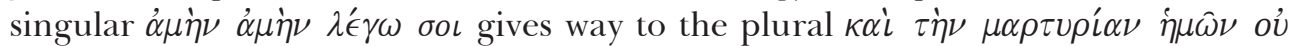
$\lambda \alpha \mu \beta \alpha \dot{\alpha} \nu \epsilon \epsilon$.

Then follows a major theological excursus on the work of the Son and the necessity for salvation, though Nicodemus himself has disappeared from the discourse by verse $11 .{ }^{19}$

The final reply of Jesus is clearly confessional as Martin Hengel points out. ${ }^{20}$ He is correct to stress the coherence of Jesus' speech with the other Jewish titles John ascribes to Jesus throughout his Gospel. However it is less clear, in my view, that this is truly at the expense of Jesus as the divine Logos as Hengel suggests. ${ }^{21}$ The discourse with Nathanael relies heavily on Jewish theological tradition and inference and the same is true for Jesus' concluding speech. He adopts Nathanael's words, not as sarcasm, but as truth and immediately exploits their significance for his own identity. Although Jesus has assumed Nathanael's belief, "Did you believe because I told you that I saw you under the fig tree?" (1:50), it is not Nathanael's "belief" that is the determinant for establishing Jesus as the Son of God. In fact, Nathanael has not believed at all! Rather, he has spoken a truth beyond anything he could comprehend though revealed subsequently to be the case. This is consistent with the hermeneutical paradigm established by John in 2:22 but which has been brought forward proleptically as a way of inserting the reader into the narrative at an early stage so as to see the end from the beginning and

This is also consistent with the style of ancient biographies where character development of the central figure is built up in their interactions with others. Warren Carter notes that biographic perspectives are created through the use of deliberate ambiguity with interactions and conflicts assessed with respect to the point of view of the narrator as well as the main figure. Thus it is necessary for Nathanael to disappear in order to throw Jesus into sharp relief. In John's Gospel, the character of Jesus undergoes no change though the attendant figures do develop. See, Warren Carter, John. Storyteller, Interpreter, Evangelist (Peabody, MA: Hendrickson Publishers, 2006), $47 \mathrm{f}$.

19 John 3:13 and 1:51 share the same imagery of heavenly access but with the further development in 3:14f of Jesus' soteriological role.

20 Richard Bauckham and Carl Mosser (eds.), The Gospel of John and Christian Theology (Grand Rapids: William B. Eerdmans, 2008), 271. See also, Martyn, History and Theology, 150.

21 For John, Jesus was always the divine Logos whose taking of human form incarnationally unites human flesh with the Godhead. Jesus thus remains the Logos in whom "the whole fullness of deity dwells bodily" (Colossians 2:9) though he can be "known" at this point only in the flesh. John revisits this ontological congruence at the conclusion of his Gospel.

PERICHORESIS 11.2 (2013) 
how John's ultimate conclusions were vindicated at the outset. In other words, it was always true that Jesus is the Son of God, the King of Israel; acknowledgement of this leads seamlessly to worship in the presence of faith but otherwise to rejection and judgement. The image of "heaven opened and the angels of God ascending and descending upon the Son of Man" (1:51) is most naturally associated with the vision of Jacob's ladder in Genesis 28:10ff. ${ }^{22}$ Contextually, this fits, with Jesus appropriating the Genesis text and viewing himself as the true Israelite representing the true Israel. ${ }^{23}$ Witherington further elaborates by suggesting that what John has in view here is not the route between heaven and earth but rather Jesus as the place where heaven and earth meet. ${ }^{24}$ This is an attractive idea and is supported by the proximity in John's account of the cleansing of the Temple at 2:1322 and the concept of Jesus' body as the new Temple (verse 21).

This part of John's Gospel concludes with a retrospective on John the Baptist at 3:22-36 and builds on the idea of Jesus' witness to himself and why this can be deemed acceptable when he was rejected by most. That is, "No one can receive anything except what has been given from heaven" (3:27). The notice in 2:23-25 whereby Jesus refuses to "entrust himself to them" also validates the narrative technique used by John which allows a major character to disappear from the discourse revealing only the self-disclosure of Jesus.

\section{Conclusion}

In this article, I have offered an alternative to the traditional historicist reading of John 1:43-51 by suggesting that Nathanael's response to Jesus is one built around the interplay of traditional theological motifs and sarcasm around the local origins of Jesus. Thus, the reader is not compelled to see radical belief emerging from Nathanael at the same time as normal doubt, quite against the construction of the narrative. This conclusion is supported using grammatical and narrative methods in John in which the speech of characters within a discourse is frequently allowed to carry much greater weight than the character could have known. For example, this is particularly apt in the case of Caiaphas at John 11:49-53 in which he rules that the Sanhedrin, "know[s] nothing at all" (verse 49). So at one level, Caiaphas is completely correct and completely wrong, yet for reasons that escalate beyond what only our narrator can confidently affirm - that Jesus' death is "... to gather into one the dispersed children of God" (verse 52). This is exactly what happens in the case of Nathanael whose sarcasm is both fitting at the level of a local appre-

\footnotetext{
22 Perhaps also Ezekiel 1:1.

23 There is intertextual precedent for this at Luke 4:21 where Jesus applies Isaiah 61:1f to himself. Another possibility arises from the Genesis Targum in which the angels moving between earth and heaven pause to see the truly pious individual who contemplates the throne of God. Cf. Christopher Rowland, "John 1:51, Jewish Apocalyptic and Targumic Tradition", New Testament Studies 30 (1984): 498-507. 
ciation of "all things Nazareth" but which transcends any temporal grasp of Jesus in his deeds and identity. The short tantalising account of Jesus' encounter with Nathanael opens up this possibility wherein it remains for Jesus alone to bear witness to his own identity and for the reader to consider their own relationship to that testimony.

\section{Bibliography}

Bauckham, Richard, and Carl Mosser, eds. The Gospel of John and Christian Theology. Grand Rapids: William B. Eerdmans, 2008.

Bernard, J. H. A Critical and Exegetical Commentary on the Gospel According to St. John. The International Critical Commentary. Edinburgh: T. \& T. Clark, 1928.

Blomberg, Craig L. Jesus and the Gospels. An Introduction and Survey. Nashville: Broadman \& Holman, 1997.

Brodie, Thomas L. The Gospel According to John. A Literary and Theological Commentary. Oxford: Oxford University Press, 1993.

Carter, Warren. John. Storyteller, Interpreter, Evangelist. Peabody, MA: Hendrickson Publishers, 2006.

Culpepper, R. Alan. Anatomy of the Fourth Gospel. A Study in Literary Design. Philadelphia: Fortress Press, 1983.

Duke, Paul. Irony in the Fourth Gospel. Atlanta: John Knox Press, 1985.

Funk, Robert W. A Greek Grammar of the New Testament and Other Early Christian Literature. Chicago: The University of Chicago Press, 1961.

Giblin, Charles Homer. "What Was Everything He Told Her She Did? (John 4.1718, 29, 39)". New Testament Studies 45 (1999): 148-52.

Hunter, A. M. According to John. Norwich: SCM Press, 1977.

Martyn, J. Louis. History and Theology in the Fourth Gospel. Louisville: Westminster John Knox Press, 2003.

Morris, Leon. Studies in the Fourth Gospel. Grand Rapids: William B. Eerdmans, 1969.

Painter, John. John. Witness and Theologian. London: SPCK, 1979.

Rae, Murray. "The Testimony of Works in the Christology of John's Gospel”. In The Gospel of John and Christian Theology, edited by Richard Bauckham and Carl Mosser, 295-310. Grand Rapids: William B. Eerdmans, 2008.

Resseguie, James L. Narrative Criticism of the New Testament. Grand Rapids: Baker Academic, 2005.

Robbins, Vernon K. Exploring the Texture of Texts. A Guide to Socio-Rhetorical Interpretation. Valley Forge: Trinity Press International, 1996.

Robbins, Vernon K. The Tapestry of Early Christian Discourse. New York: Routledge, 1996.

Rowland, Christopher. "John 1:51, Jewish Apocalyptic and Targumic Tradition". New Testament Studies 30 (1984): 498-507. 
Smalley, Stephen S. John. Evangelist and Interpreter. Nashville: Thomas Nelson Publishers, 1984.

Turner, Nigel. Syntax. Grammar of New Testament Greek. Edinburgh: T. \& T. Clark, 1963.

Westcott, B. F. The Gospel According to St. John. Grand Rapids: William B. Eerdmans, 1881, reprinted 1981.

Witherington, Ben, III. John's Wisdom. A Commentary on the Fourth Gospel. Cambridge: The Lutterworth Press, 1995.

PERICHORESIS $11.2(2013)$ 